\title{
GAMBARAN TINGKAT STRES KELUARGA YANG DITINGGALKAN KERJA KE LUAR NEGERI OLEH ANGGOTA KELUARGA
}

\author{
Livana PH ${ }^{1}$, Failila Khosandika ${ }^{1}$, Mohammad Fatkhul Mubin ${ }^{2}$ \\ ${ }^{1}$ Program Studi Ners STIKES Kendal \\ ${ }^{2}$ FIKKes Universitas Muhammadiyah Semarang \\ livana.ph@gmail.com
}

\begin{abstract}
ABSTRAK
Perubahan kondisi sosial akan mempengaruhi Tenaga Kerja Indonesia (TKI) yang berkerja di luar negeri maupun keluarganya, awalnya tentu membawa dampak yang cukup berat baik yang dirasakan oleh yang bersangkutan maupun anggota keluarganya. Kondisi ini secara kejiwaan akan berdampak pada tingkat stres yang bersangkutan dan anggota keluarganya yang cukup tinggi. Dari kebiasaan bersama menjadi tidak ada, hal ini langsung atau tidak langsung berdampak pada pola fikir dan sikap para keluarga yang ditinggalkan. Penelitian bertujuan untuk mengetahui gambaran tingkat stres keluarga yang ditinggal kerja ke luar negeri oleh anggota keluarga. Jenis penelitian deskriptif eksploratif. Populasi dalam penelitian ini adalah keluarga yang ditinggalkan oleh anggota keluarganya ke luar negeri di Desa Taman Gede Kecamatan Gemuh Kabupaten Kendal sebanyak 55 responden. Teknik sampling menggunakan sampling jenuh. Proses pengumpulan data dilakukan dengan mengisi lembar observasi berupa kuesioner. Data dianalisis secara univariat dengan menghitung distribusi frekuensinya. Hasil penelitian menunjukkan mayoritas keluarga yang ditinggal kerja ke luar negeri oleh anggota keluarga mengalami stres pada tingkat stres sedang. Pelayanan kesehatan dapat memberukan intervensi kepada keluarga yang ditinggal kerja ke luar negeri oleh anggota keluarganya sebagai upaya untuk mengatasi tingkat stres yang dialaminya.
\end{abstract}

Kata kunci: Keluarga yang ditinggal kerja ke luar negeri, stres.

\section{FAMILY STRESS LEVEL THAT LEFT WORK OUTSIDE BY FAMILY MEMBERS}

\begin{abstract}
Changes in social conditions will affect Indonesian Workers (TKI) who work abroad and their families, initially it will have a quite heavy impact both felt by those concerned and their family members. This condition will have a psychological impact on the stress level concerned and family members who are quite high. From shared habits to non-existent, this directly or indirectly affects the thinking patterns and attitudes of the families left behind. The study aims to describe the level of family stress left by work abroad by family members. Type of explorative descriptive research. The population in this study were families left by family members abroad in Taman Gede Village, Gemuh District, Kendal District, as many as 55 respondents. The sampling technique uses saturated sampling. The process of data collection is done by filling in the observation sheet in the form of a questionnaire. Data were analyzed univariately by calculating the frequency distribution. The results showed that the majority of families left to work abroad by family members experience stress at moderate stress levels. Health services can provide intervention to families who are left to work abroad by family members in an effort to overcome the level of stress they experience.
\end{abstract}

Keywords: Families left behind to work abroad, stress.

\section{PENDAHULUAN}

Di Indonesia mengalami terbatasnya lapangan pekerjaan di dalam negeri dan banyaknya tenaga kerja yang tidak tertampung pada dunia usaha didalam negeri, serta tuntutan ekonomi keluarga yang makin tinggi mendorong sebagian masyarakat Indonesia, khususnya Desa Taman Gede Kabupaten Kendal untuk mencari pekerjaan di luar negeri. Bekerja diluar negeri. Bekerja di luar negeri yang biasa dapat meningkatkan keluarga dikenal dengan Tenaga Kerja Indonesia (TKI) merupakan pilihan yang paling dianggap menakjubkan karena penghasilan yang akan diperoleh relatif besar dan diharapkan dapat meningkatkan kesejahteraan diri dan serta keluarga.

Indonesia merupakan negara dengan tingkat pertumbahan dan perkembangan ekonomi mencapai $6,3 \%$ pada tahun 2002 yang sedikit 
turun dari angka $6,5 \%$ pada tahun sebelumnya. Dengan demikian tingkat pengangguran mencapai 14 juta, taksiran 14 juta pengangguran untuk indonesia ini masih cukup rendah karena belum ditambahkan jumlah pengangguran di luar pulau Jawa, Madura dan Bali (ISEIE, 2005).

Dari tahun ke tahun jumlah mereka yang bekerja ke luar negeri semakin meningkat. Pada tahun 2010 berdasarkan data yang ada di Badan Nasional Penempatan dan perlindungan Tenaga Kerja Indonesia, Tenaga Kerja Indonesia (TKI) yang ada di luar negeri sampai dengan tahun 2012 mencapai 3.998.592 orang. Secara rinci Tenaga Kerja Indonesia (TKI) tersebar diberbagai negara seperti Saudi Arabia, Malaysia, Taiwan, Singapura, Hongkong dan lain lain.

Menurut data Dinas Tenaga Kerja dan Transmigrasi provinsi Jawa Tengah pada tahun 2011 mencapai 231.587 orang. Berdasarkan data tersebut, maka dapat diketahui bahwa dari 33 kabupaten/kota di Jawa Tengah, terdapat 13 kabupaten/kota yang merupakan penyumbang terbesar Tenaga kerja indonesia (TKI) di provinsi Jawa Tengah. Daerah kabupaten tersebut merupakan kantong-kantong tenaga kerja indonesia (TKI) yang telah menyuplai kebutuhan tenaga kerja di luar negeri yang berasal dari Indonesia. Dari berbagai daerah Kabupaten yang ada di Jawa Tengah, Kabupaten Kendal menduduki urutan ketiga pada tahun 2011 yang berjumlah 14.020 orang. Di wilayah kecamatan Gemuh kabupaten Kendal untuk tahun 2011, penempatan tenaga kerja indonesia (TKI) di luar negeri berjumlah 1613 orang terdiri dari 512 orang laki-laki dan 1101 perempuan. Adapun penempatan sektor formal sebanyak 420 dan sisanya merupakan sektor informal.

Jumlah Tenaga Kerja Indonesia (TKI) di luar negeri sebanyak 4.822. TKI yang mengalami penganiayaan pada tahun 2009 sejumlah 1.193 orang. Jumlah itu naik tajam diatas 30 persen, tepatnya 39 persen dibandingkan tahun sebelumnya 3.470 jiwa. Hal itu terungkap dalam data pelayanan TKI di Terminal selapajang bandara Soekarno Hatta oleh Badan Nasional Penempatan dan Perlindungan TKI (BNP2TKI : 2010). Data Kementerian Tenaga dan Transmigrasi (Kemenakertrans) mencatat kasus yang menimpa TKI selama tahun 2010 sebanyak 60.399 kasus dan tahun 2011 sebanyak 44.573 kasus (Solicha, 2012).

Perubahan kondisi sosial akan mempengaruhi Tenaga Kerja Indonesia (TKI) yang berkerja di luar negeri maupun keluarganya, awalnya tentu membawa dampak yang cukup berat baik yang dirasakan oleh yang bersangkutan maupun anggota keluarganya. Kondisi ini secara kejiwaan akan berdampak pada tingkat stres yang bersangkutan dan anggota keluarganya yang cukup tinggi. Dari kebiasaan bersama menjadi tidak ada, hal ini langsung atau tidak langsung berdampak pada pola fikir dan sikap para keluarga yang ditinggalkan.

Setiap orang mengalami stres dari waktu ke waktu, dan umumnya seseorang dapat mengadaptasi stres jangka panjang atau menghadapi stress jangka pendek sampai stress tersebut berlalu. Stres dapat menimbulkan tuntutan yang besar pada seseorang, dan jika orang tersebut tidak dapat mengadaptasi, maka dapat terjadi penyakit. Segala macam bentuk stress pada dasarnya disebabkan oleh kurang mengertinya individu akan keterbatasanketerbatasannya sendiri. Ketidakmampuan untuk melawan keterbatasan inilah yang akan menimbulkan frustasi, konflik, gelisah, dan rasa bersalah yang merupakan tipe-tipe dasar stress (Anotoga, 2006). Stress adalah suatu keadaan dimana beban yang dirasakan seseorang tidak sepadan dengan kemampuan untuk mengatasi beban itu (Markam \& Slamet, 2003).

Keluarga yang akan ditinggalkan oleh anggota keluarga berangkat ke luar negeri tentu akan mengalami stres karena akan tidak bertemu dalam jangka waktu yang cukup lama. keluarga akan merasa tidak nyaman jika ada kabar buruk tentang anggota keluarga mereka yang terkena masalah diluar negeri. Kondisi ini akan menjadi beban kecemasan tersendiri bagi keluaraga yang ditinggalkan. Beradasarkan hasil studi pendahuluan dari perusahaan penyalur Tenaga Kerja di Kecamatan Gemuh bahwa di wilayah desa Taman gede kecamatan Gemuh terdapat 55 warga yang bekerja ke luar negeri. Hasil wawancara terhadap 5 responen di desa Taman Gede Kecamatan Gemuh yang anaknya pergi ke luar negeri, 3 diantaranya mengatakan stress bila mendapat kabar anaknya mendapatkan majikan yang kasar, 2 diantaranya mengatakan stres pada awal kepergian anaknya tetapi stress itu berkurang ketika anaknya memberi kabar bahwa dirinya merasa aman dan tidak mengalami hambatan dalam bekerja di luar negeri. Penelitian ini bertutuan untuk mengetahui gambaran Tingkat Stress Keluarga yang ditinggal kerja ke luar negeri oleh anggota keluarga di desa Taman Gede Kendal"' 


\section{METODE}

Jenis penelitian ini adalah deskriptif eksploratif. Populasi dalam penelitian ini adalah keluarga yang ditinggalkan oleh anggota keluarganya ke luar negeri di Desa Taman Gede Kecamatan Gemuh Kabupaten Kendal sebanyak 55 responden. Teknik sampling yang digunakan dalam penelitian ini adalah menggunakan sampling jenuh. Adapun kriteria inklusi penelitian ini yaitu (1)Bapak dan ibu yang ditinggalkan anaknya (belum menikah) keluar negeri. (2)Bapak dan ibu yang bersedia menjadi responden. Kriteria eksklusi dalam penelitian ini adalah : Keluarga yang pada tengah-tengah penelitian anaknya pulang dari luar negeri.

Proses pengumpulan data dilakukan dengan mengisi lembar observasi. Lembar observasi menggunakan kuesioner dengan 10 pertanyaan. Kuesioner dalam penelitian ini dibagi menjadi 2 bagian yaitu, kuesioner A yang digunakan untuk mengetahui karakteristik umur, jenis kelamin dan penghasilan pada responden. Kuesioner B digunakan untuk mengetahui tingkatan stres yang terjadi pada keluarga yang ditinggalkan oleh anggotanya ke luar negeri. Dengan score $0-4$. Nilai score 0 artinya tidak pernah, nilai score 1 artinya hampir tidak pernah, nilai score 2 artinya kadang, nilai score 3 artinya cukup sering, nilai score 4 artinya sangat sering. Data dianalisis secara univariat dengan menghitung distribusi frekuensinya.

\section{HASIL}

\section{Karakteristik responden}

Hasil menelitian menunjukkan umur 36-60 tahun dengan hasil tertinggi sebanyak 51 responden $(92,7 \%)$, umur $21-35$ tahun sebanyak 3 responden $(5,5 \%)$ dan umur $>61$ tahun sebanyak 1 responden $(1,8 \%)$. Rata-rata atau mean dari umur 45,55 , modus merupakan nilai yang sering muncul berdasarkan umur responden adalah 47, nilai tengah dari umur atau nilai mediannya adalah 47,00. Rata-rata umur responden penelitian di desa Taman Gede Kendal adalah 45 tahun dan sebagian besar responden berumur 47 tahun. Jenis kelamin mayoritas yaitu perempuan sebanyak 30 orang $(54,4 \%)$ dengan presentase terendah yaitu laki-laki sebanyak 25 orang (45,5\%). Penghasilan responden di Desa Taman Gede berpenghasilan kurang sebanyak 30 responden $(54,5 \%)$, berpenghasilan cukup sebanyak 21 responden $(38,2 \%)$ dan yang berpenghasilan lebih sebanyak 4 responden $(7,3 \%)$.

\section{Gambaran tingkat stres}

Gambaran tingkat stres keluarga menunjukkan bahwa gambaran tingkat stres pada responden sebagian besar mengalami stres sedang sebanyak 40 responden $(72,7 \%)$, sedangkan nilai rata-rata untuk tingkat stres atau meannya adalah 15,24 yang dikategorikan dalam stress sedang.

\section{PEMBAHASAN}

\section{Karakteristik Responden}

a. Umur

Responden berumur 36-60 tahun yaitu sebanyak 51 responden $(92,7 \%)$, ini merupakan data terbanyak dibandingkan dari responden yang berumur 21-35 dan umur > 61 tahun. Responden yang berumur $21-35$ tahun berjumlah 7 responden $(5,5 \%)$ dan responden yang berumur $>61$ tahun berjumlah 1 responden $(1,8 \%)$ Berdasarkan hasil penelitian menunjukan bahwa responden yang berumur 36-60 tahun lebih banyak dibandingkan dengan umur 21-35 tahun ataupun umur $>61$ tahun yang cenderung memikirkan masalah keluarga, ekonomi, dan juga memikirkan masalah pribadi yang sedang dihadapinya. Hasil penelitian ini sesuai dengan teori Budiono (2002) yang menyatakan bahwa perubahan umur mempengaruhi perilaku seseorang melalui perjalanan umurnya yang disababkan karena proses pendewasaan, maka seseorang akan lebih mudah melakukan adaptasi perilaku hidup dengan lingkungannya. Hasil penelitian ini sesuai Menurut Suryabudhi (2003), seseorang yang menjalani hidup secara normal dapat diasumsikan bahwa semakin lama hidup maka pengalaman semakin banyak, pengetahuan semakin luas, keahliannya semakin mendalam dan kearifannya semakin baik dalam pengambilan keputusan tindakannya. Hasil penelitian ini sesuai dengan teori Notoatmodjo (2007), umur adalah lama hidup individu terhitung saat mulai dilahirkan sampai berulang tahun, semakin cukup umur tingkat kematangan seseorang akan lebih matang dalam berfikir dan bekerja. Dari segi kepercayaan yang lebih dewasa akan lebih dipercayai dari pada orang yang belum cukup tinggi kedewasaannya. Hal ini sebagai akibat dari pengalaman dan kematangan jiwa seseorang. Hasil penelitian ini sesuai Siagian (2008) yang menyatakan karakteristik individu dapat dilihat dari umur, jenis kelamin dan status perkawinan.

\section{b. Jenis Kelamin}

Hasil penelitian menunjukkan bahwa sebagian besar responden berjenis kelamin perempuan sebanyak 30 responden $(54,4 \%)$ dan laki-laki sebanyak 25 responden $(45,5 \%)$. Hal ini dikarenakan perempuan kebanyakan pekerja 
rumah tangga dan perempuan lebih banyak waktu luang dibandingkan laki-laki yang kebanyakan sibuk bekerja. Menurut Hungu (2007) jenis kelamin (seks) adalah perbedaan antara perempuan dengan laki-laki secara biologis sejak tanggal lahir. Efek menopause berdasarkan teori waluyo (2010), dijelaskan bahwa secara medis hanya ada tiga gejala menopause, yaitu menstruasi yang kacau, semburan panas dan keringnya vagina. Semua itu disebabkan oleh penurunan kadar hormone estrogen yang diproduksi tubuh. Gejala-gejala lain yang kadang juga sangat mengganggu adalah gejala emosional yang disebabkan oleh meningkatnya kadar Follical stimulating hormone (FSH), hormone perangsang folikel telur dan luteinizing hormone (LH). Gejala emosional menurut menopause yang disebabkan membanjirinya FSH dan LH yang sering dialami wanita menjelang menopause, antara lain,suasana hati yang berubah-ubah, mudah marah dan mudah sedih tanpa sebab yang jelas, depresi, saling cemas dan gelisah tanpa sebab yang jelas, alergi meningkat dan sulit tertidur pulas.

\section{c. Penghasilan}

Hasil penelitian menunjukkan bahwa mayoritas penghasilan responden berpenghasilan kurang sebanyak 30 responden $(54,5 \%)$, yang berpenghasilan cukup sebanyak 21 responden ( $38,2 \%$ ) dan yang berpenghasilan lebih sebanyak 4 responden $(7,3 \%)$. Berdasarkan hasil penelitian mayoritas responden berpenghasilan kurang yang di ukur dengan standar UMR kabupaten Kendal sebanyak Rp 904.500,00. Karena sebagian besar penduduk desa Taman Gede berpencaharian sebagai Buruh Tani, petani dan buruh bangunan. Berdasarkan teori Friedman (1998) yang dikutip oleh Setiadi (2010) hasil penelitian menunjukan bahwa fungsi ekonomi keluarga belum terpenuhi sempurna dimana fungsi ekonomi merupakan suatu kebutuhan keluarga secara ekonomi dan tempat untuk mengembangkan kemampuan individu dalam meningkatkan penghasilan untuk memenuhi kebutuhan keluarga.

\section{Gambaran Tingkat Stres pada keluarga yang ditinggalkan oleh anggota keluarga ke luar negeri}

Responden mengalami tingkat stress sedang sebanyak 40 responden $(72,7 \%)$, sedangkan jumlah tingkat stress ringan dan stress berat lebih kecil dibandingkan dengan stress sedang. Jumlah tingkat stress ringan dan stress berat sebanyak 13 responden $(23,6 \%)$, dan jumlah stress berat sebanyak 2 responden $(3,6 \%)$. Berdasarkan hasil penelitian menunjukan bahwa responden yang mengalami stres sedang adalah antara umur 36-60 tahun dan kebanyakan berjenis kelamin perempuan karena seorang ibu lebih memiliki keterikatan batin kepada anaknya. Hasil penelitian ini sesuai teori Hawari (2008) karena stress sedang termasuk stress tahapan II Keluhankeluhan yang sering dikemukakan oleh seseorang merasa letih sewaktu bangun pagi yang seharusnya merasa segar, merasa mudah lelah sesudah makan siang, sedangkan stress ringan tergolong pada stress tahap I Tahapan ini merupakan tahapan paling ringan, dan biasanya disertai dengan perasaan-perasaan tertentu perasaan tersebut antara lain adalah semangat bekerja besar, berlebihan (over acting), jika melewati stress tahap I (stress ringan) dan stress tahap II (stress sedang) maka jika stress berat mengalami keluhan dari stress tahap III sampai tahap stress VI.

\section{Keterbatasan Penelitian}

Penelitian ini hanya dilakukan di lingkup wilayah yang masih kecil, hanya dilakukan di Desa Taman Gede tidak di seluruh Kecamatan Gemuh Kabupaten Kendal. Dalam penelitian ini hanya menggunakan kuesioner untuk mengetahui tingkat kesetresan, sehingga masalah tingkat kesetresan belum dipahami secara detail.

\section{Implikasi untuk Keperawatan}

Penelitian ini membawa implikasi pada pelayanan keperawatan terhadap keluarga yang ditinggalkan oleh anaknya yang kerja di Luar Negeri. Dalam upaya untuk mengurangi tingkat kesetresan, tidak hanya terfokus pada keluarga saja namun orang yang terdekat dengan keluarga juga. Hasil penelitian berimplikasi kepada pemberian informasi kepada keluarga sehingga tingkat kesetresan menurun atau berkurang. Hasil penelitian dapat menambah bukti nyata untuk meningkatkan ilmu pengetahuan di bidang keperawatan khususnya tentang tingkat kesetresan. Selain itu, hasil penelitian ini dapat dijadikan referensi untuk penelitian selanjutnya terkait dengan tingkat stress keluarga yang ditinggal ke Luar Negeri.

\section{SIMPULAN DAN SARAN Simpulan}

Berdasarkan hasil penelitian dan pembahasan dapat disimpulkan sebagai beikut :

1. Karakteristik responden mayoritas berusia dewasa madya (36-60 tahun) sebanyak 51 responden $(92,7 \%)$, mayoritas berjenis kelamin perempuan sebanyak 30 responden $(54,4 \%)$, mayoritas berpenghasilan kurang sebanyak 30 responden $(54,5 \%)$ 
2. Tingkat Stress keluarga yang ditinggalkan oleh Anggota Keluarga ke luar negeri di Desa Taman Gede Kendal mayoritas mengalami stress sedang yaitu sebanyak 40 responden $(72,7 \%)$.

\section{Saran}

Berdasarkan hasil penelitian, maka dapat dikemukakan beberapa saran sebagai berikut :

1. Bagi Keluarga atau masyarakat Keluarga atau masyarakat menyadari bahwa ada masalah pada dirinya, saat ditinggal ke luar negeri yaitu stres sehingga perlu mendiskusikan sebelum pergi ke luar negeri.

2. Bagi Pelayanan Keperawatan

Pelayanan kesehatan dapat memberukan intervensi kepada keluarga yang ditinggal kerja ke luar negeri oleh anggota keluarganya sebagai upaya untuk mengatasi tingkat stres yang dialaminya.

\section{DAFTAR PUSTAKA}

Anoraga, Pandji. (2006). Psikologi Kerja. Jakarta: PT. Rineka Cipta.

Badan Nasional Penempatan dan Perlindungan Tenaga Kerja Indonesia (BNP2TKI). (2010). http://asik.bnp2tki.go.id/login.php. Provinsi Jawa Barat, Bandung.
Boediono, (2002), Ekonomi Makro: Seri Sinopsis Pengantar Ilmu Ekonomi No.1 Edisi 2. Yogyakarta: BPEE

Hawari, Dadang. (2008). Manajemen Stres Cemas dan Depresi. Jakarta : FK Universitas Indonesia

Hungu. 2007. Demografi Kesehatan Indonesia. Jakarta: Grasindo.

I.S, Suprapti Slamet., Sumarmo Markam. (2003). Pengantar Psikologi Klinis, Jakarta: Universitas Indonesia Press.

Notoatmodjo, S. 2007. Promosi Kesehatan dan Ilmu Perilaku. Jakarta : Rineka Cipta

Siagian, Sondang., P. (2008). Manajemen Sumber Daya Manusia (Edisi. Pertama). Jakarta: Binapura Aksara

Suryabudhi, maria. 2003. Cara Merawat bayi dan Anak-anak. Bandung: Alfabeta.

Waluyo.2010. Perpajakan Indonesia. Jakarta : Salemba Empat 